TAO, Vol. 16, No. 1, 57-73, March 2005

\title{
Foraminiferal Oxygen Isotope Stratigraphy and High-Resolution Organic Carbon, Carbonate Records from the Okinawa Trough (IMAGES MD012404 and ODP Site 1202)
}

\author{
Yuan-Pin Chang ${ }^{1}$, Shiu-Mei Wu ${ }^{1}$, Kuo-Yen $\mathrm{Wei}^{2}$, Masafumi Murayama ${ }^{3}$, \\ Hodaka Kawahata ${ }^{4}$ and Min-Te Chen ${ }^{1, *}$
}

(Manuscript received 23 June 2004, in final form 8 November 2004)

\begin{abstract}
Biogenic carbonate and organic carbon content of two deep sea cores (MD012404 and ODP site 1202) are measured to reconstruct surface ocean productivity variations in areas of the Okinawa Trough in the Western Pacific where the modern climate is highly sensitive to the East Asian monsoon and precipitation/river runoff. Based on foraminiferal isotope stratigraphy and $\mathrm{AMS}{ }^{14} \mathrm{C}$ dating, the age models of the cores indicate that core MD012404 shows relatively low sedimentation rates with $50 \mathrm{~cm} \mathrm{ky}^{-1}$ on average, and that the sedimentation rates in core ODP 1202 are extremely high with an average of $500 \mathrm{~cm} \mathrm{ky}^{-1}$. Total organic carbon (TOC) and carbonate contents in core ODP 1202 are $0.56 \%$ and $6.80 \%$ on average, respectively, and are $0.62 \%$ and $15.86 \%$, respectively, in core MD012404. The relatively high carbonate contents in core MD012404 imply high carbonate productivity in the central Okinawa Trough. The sedimentary composition of core ODP 1202 is composed principally of terrestrial silt and clay, indicating enormous terrestrial flux from land and a carbonate dilution effect in the southern Okinawa Trough. The variations of TOC in core MD012404 reveal a dominant $23 \mathrm{kyr}$ cycle, suggesting that the surface ocean productivity in the Okinawa Trough area appears to be driven by precession changes in the East Asian monsoon. High-frequency oscillations in the

\footnotetext{
1 Institute of Applied Geosciences, National Taiwan Ocean University, Keelung, Taiwan, ROC

2 Department of Geosciences, National Taiwan University, Taipei, Taiwan, ROC

${ }^{3}$ Center for Advanced Marine Core Research, Kochi University, Kochi, Japan

${ }^{4}$ Geological Survey of Japan, National Institute of Advanced Industrial Science and Technology (AIST), Tsukuba-higashi 1-1-1, Ibaraki, Japan

* Corresponding author address. Prof. Min-Te Chen, Institute of Applied Geosciences, National Taiwan Ocean University, Keelung, Taiwan, ROC; E-mail: mtchen@mail.ntou.edu.tw
} 


\title{
TOC records in core MD012404 also indicate that the surface ocean pro- ductivity changes share a similar structure with the climatic variability char- acteristic of northern high latitudes.
}

\author{
(Key words: IMAGES, ODP, Total organic carbon, Calcium carbonate, \\ Okinawa Trough, Paleoceanography, Climate change, East Asian monsoon)
}

\section{INTRODUCTION}

Terrestrial sediments compose a large fraction of sediments deposited in the Okinawa Trough of the Western Pacific. Sediments deposited in the Okinawa Trough were mainly derived from China via the Yangtze River through the continental shelves of the East China Sea (Kao et al. 2003). Terrestrial sediments derived from Taiwan Island might also contribute to the Okinawa Trough sediments variably (Su and Huh 2002). Waters of the Okinawa Trough are predominated by the Kuroshio Current and exhibit high sea-surface temperatures (SST) $\left(>20^{\circ} \mathrm{C}\right)$ and high salinity $(>34.5 \mathrm{psu})$.

Previous studies showed that during the Last Glacial Maximum (LGM), the sea level was $\sim 120 \mathrm{~m}$ lower than it is today (Fairbanks 1989). In this context, a large part of the East China Sea continental shelf was not submerged, and the coastline would have been much closer to the Okinawa Trough then it is at present. Therefore, enormous amounts of terrestrial sediments could have been transported from land and the shelf to the Okinawa Trough during the glacial period, which consequently resulted in the Western Pacific being a good site with highsedimentation rates that make it ideal for studying high-resolution history of ocean and climate changes.

A growing number of late Quaternary paleoceanographic records suggest an active component for the Western Pacific in global climate change (Jian et al. 1996, Li et al. 1997, Shieh et al. 1997, Ujiié and Ujiié 1999, Xu and Oda 1999, Hsueh 2000, Jian et al. 2000a, Jian et al. 2000b, Li et al. 2001, Ujiié et al. 2001, Tanaka 2003, Ujiié et al. 2003). These studies suggested that the Kuroshio would have migrated to the east off Ryukyu Island and thus may not have flowed into the Okinawa Trough during the LGM. Moreover, the glacial climate in the Okinawa Trough also experienced high-frequency oscillations as witnessed in northern high latitude regions (Liu et al. 1999). A stalagmite study from Hulu Cave, near Nanjing, China, also suggested a synchronous relationship between East Asian summer monsoon precipitation and a warm interstadial climate (Wang et al. 2001). Such evidence indicates global climatic dynamics well expressed in the ocean climate of the Okinawa Trough and suggests a need to retrieve long records for documenting long-range paleoceanographic and paloclimatic changes to advance our understanding of the coupling of climatic processes between low and high latitudes during the last glacial-interglacial cycles.

Most previous marine core studies relied upon short cores. An IMAGES 2001 cruise (Bassinot et al. 2002) and an ODP Leg 195 (Shipboard Scientific Party 2002) were designed to obtain long cores for studying the long and continuous paleoceanogaphic history of the Kuroshio Current in the Western Pacific. For this purpose, in this study we have generated a high- 
resolution time series of benthic foraminiferal oxygen isotopes from core MD012404, and total organic carbon (TOC) and biogenic carbonate contents from both cores MD012404 and ODP 1202 to reconstruct the orbital and millennial-to-centennial scale variations of surface ocean productivity and sedimentation modes in the Okinawa Trough, and we also discuss the possible climate mechanisms that caused these variations.

\section{METHOD AND MATERIALS}

\subsection{The Sediment Cores}

ODP site 1202 is located at the southernmost part of the Okinawa Trough $\left(24^{\circ} 48.24^{\prime} \mathrm{N}\right.$, $122^{\circ} 30^{\prime} \mathrm{E}$; water depth $1274 \mathrm{~m}$ ) (Fig. 1), and was chosen to obtain a high-resolution record of the Late Quaternary history of the Kuroshio (ODP Shipboard Scientific Party 2002). Two sediment sequences drilled at Holes 1202B and 1202D with penetration depths of $140 \mathrm{~m}$ and $410 \mathrm{~m}$, respectively, were spliced into a composite section that was used in this study. Detailed sedimentological observations and sampling work were conducted at the ODP Gulf Repository, Texas A\&M University (Huang et al. 2005). Samples were preserved in plastic boxes, freezer stored, and then freeze-dried and ground into powder at the Core Repository and Laboratory, National Center for Ocean Research (CRL, NCOR) at National Taiwan Ocean University (NTOU).

The IMAGES core MD012404 was taken at $26^{\circ} 38.84^{\prime} \mathrm{N}, 125^{\circ} 48.75^{\prime} \mathrm{E}$ with water depth $1397 \mathrm{~m}$ (Bassinot et al. 2002). The total length of the core is $43.67 \mathrm{~m}$. The sediment core was sliced into $1 \mathrm{~cm}$ thick segments on board during the cruise. Approximately $10 \mathrm{~g}$ wet subsamples were taken from the slice samples at intervals of $5 \mathrm{~cm}$, placed in sealed plastic bags and stored in a core refrigerator in CRL, NCOR at NTOU for the purpose of conducting foraminifer stable isotope and biogenic sediment component analyses.

\subsection{Stable Isotope Analysis}

Shells of Uvigerina spp., the most abundant benthic foraminifer in core MD012404, were picked out to establish an isotope stratigraphy. Approximately 10 to 15 specimens of $>250 \mu \mathrm{m}$ in size were picked up and cleaned carefully and quickly in an ultrasonic bath with methanol 5 times. After removing the methanol relict, we immersed all benthic foraminifer shell samples in a $\mathrm{NaOCl}$ solution for at least 24 hours in order to remove lipids and organic matter. We cleaned the shells with Milli Q water 5 times then dried overnight in an oven at $50^{\circ} \mathrm{C}$. We kept the samples in vials and crushed the shells gently with a glass needle for mixing fragments well before measuring. All samples were analyzed using a Micromass IsoPrime isotope ratio mass spectrometer housed in the Geological Survey of Japan, National Institute of Advanced Industrial Science and Technology (AIST) at Tsukuba, Japan. The NBS-19 was used as the carbonate standard for calibrating the foraminifer shell samples to the Peedee belemnite (PDB). The oxygen isotope record of ODP 1202 is published in this volume and also is used here for the purpose of stratigraphy and for comparing these two records under a common chronostatigraphic framework (Wei et al. 2005). 


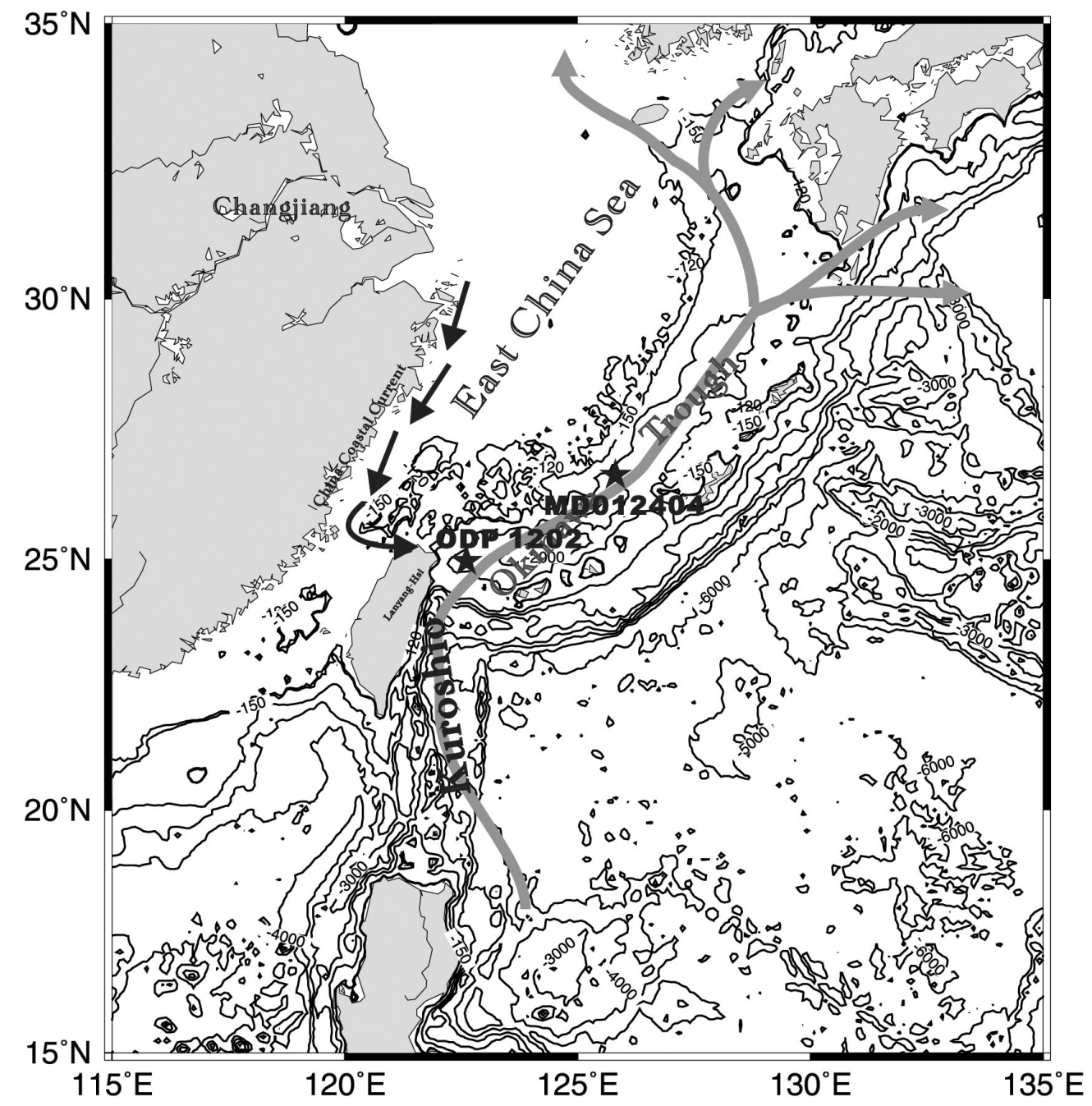

Fig. 1. Location map of the two cores, ODP1202 and MD012404. The Kuroshio Current that flows through the Okinawa Trough as indicated on the map. The Chinese Coastal Current is indicated by black arrows along the mainland coastline.

\subsection{Total Organic Carbon and Carbonate}

We analyzed 864 and 359 samples from cores MD012404 and ODP 1202, respectively, for their contents in TOC and carbonate. All wet sediment samples for the biogenic analyses were freeze-dried and ground into powder with pestle and mortar; the powder was then stored in glass vials prior to analysis. Fine-grain powder was required when grinding, and the large, 
visible fragments of Scaphopoda and Pelecypoda were removed. Samples of approximately $0.1 \mathrm{~g}$ powdered sediment were placed in carbonless crucibles and covered with copper pellets, then heated to $750^{\circ} \mathrm{C}$ in a HORIBA- 8210 Carbon Analyzer. By calculating the partial pressure of $\mathrm{CO}_{2}$ released from the sediment, we were allowed to estimate the total carbon (TC) content of the sediments. To calculate the carbonate content of the sediment, powdered samples of approximately $0.2 \mathrm{~g}$ were treated with $1 \mathrm{~N}$ hydrochloric acid in sealed anti-acid boxes for 3 days (Chang et al. 1991) to remove the total inorganic carbon (TIC) content. After the acid treatment, the samples were dried in an oven at $50^{\circ} \mathrm{C}$ for at least 12 hours. Acidified samples were again heated to $750^{\circ} \mathrm{C}$ in the Carbon Analyzer to collect $\mathrm{CO}_{2}$ gases for estimating TOC content. The difference between the measurements of TC and TOC was defined as the TIC and was used to estimate the carbonate content. Carbonate content was calculated by the following formula:

$\mathrm{TIC}(\%)=\mathrm{TC}(\%)-\mathrm{TOC}(\%)$

Carbonate $(\%)=$ TIC $(\%)$ X $(100 / 12)$.

\section{RESULTS AND DISCUSSION}

\subsection{MD012404 Age Model}

Oxygen isotopes of benthic foraminifer Uvigerina spp in core MD012404 are shown in Fig. 2. A graphic correlation method was adopted in reconstructing the isotope stratigraphy (Prell et al. 1986), and nine age control points were identified and have been translated into absolute ages in the SPECMAP Stack (Imbrie et al. 1984, Pisias et al. 1984, Martinson et al. 1987) (Fig. 2; Table 1). The age model of core MD012404 also includes five AMS ${ }^{14} \mathrm{C}$ ages (converted to calendar ages with CALIB 4.3) measured on planktic foraminifers Globigerinoides ruber and G. sacculifer of samples from the upper $14 \mathrm{~m}$ of the core (Fig. 2; Table 1). Based on the age model, the age-depth relationship (Fig. 3a) suggests that the sedimentation of core MD012404 was nearly continuous over the past 100,000 years.

The estimated average sedimentation rate based on this age model is $\sim 50 \mathrm{~cm} \mathrm{ky}^{-1}$, varying from $\sim 100$ to $20 \mathrm{~cm} \mathrm{ky}^{-1}$ (Fig. 3b). The anomalously high sedimentation rate estimated for the Late Holocene portion of the record may have resulted from a stretching of the upper part of the sediments collected with the giant piston core CALYPSO on board the RVMarion Dufresne (Szeremeta et al. 2000, Thouveny et al. 2000). The relatively low sedimentation rates for MIS 5 might also be biased by the uncertainties in the assignments of age control points at the bottom of the core. For most intervals of the record from early MIS 1 to MIS 4, the sedimentation rates stay relatively stable within a range from $\sim 60$ to $40 \mathrm{~cm} \mathrm{ky}^{-1}$ and reach maximums in the transition from interglacial to glacial MIS 2 and MIS 4 (Fig. 3b). This high sedimentation rate is observed for the first time in the central Okinawa Trough in comparison with previous studies (Li et al. 1997, Ujiié and Ujiié 1999, Li et al. 2001). Though the sedimentation rates are slightly higher in the intervals from interglacial to glacial times, overall there is no obvious glacial-interglacial pattern of sedimentation rate changes in this record 


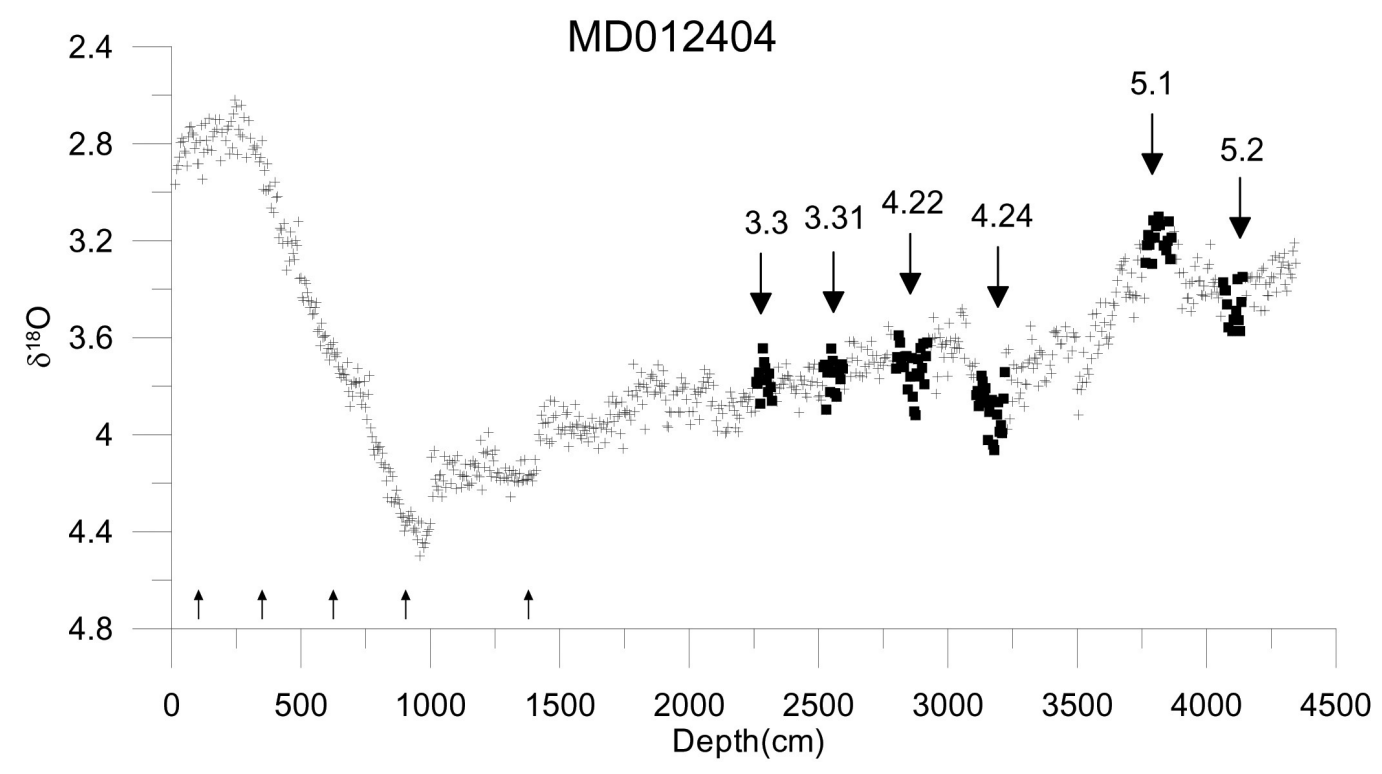

Fig. 2. AMS ${ }^{14} \mathrm{C}$ dating and age control points based on oxygen stable isotope stratigraphies used for the age model of core MD012404.

Table 1. Age control points of MD012404.

\begin{tabular}{rrr}
\hline Age (kyr) & Depth (cm) & \multicolumn{1}{c}{ Event } \\
\hline 2.0 & 104.5 & AMS-C $^{14}$ \\
6.9 & 349.5 & AMS-C $^{14}$ \\
12.9 & 624.5 & AMS-C $^{14}$ \\
16.9 & 904.5 & AMS-C $^{14}$ \\
26.0 & 1379.5 & AMS-C $^{14}$ \\
50.2 & 2289.5 & 3.3 \\
55.5 & 2557 & 3.31 \\
64.1 & 2859.5 & 4.22 \\
70.8 & 3164.5 & 4.24 \\
79.3 & 3814.5 & 5.1 \\
91.0 & 4102 & 5.2 \\
\hline
\end{tabular}


(a)
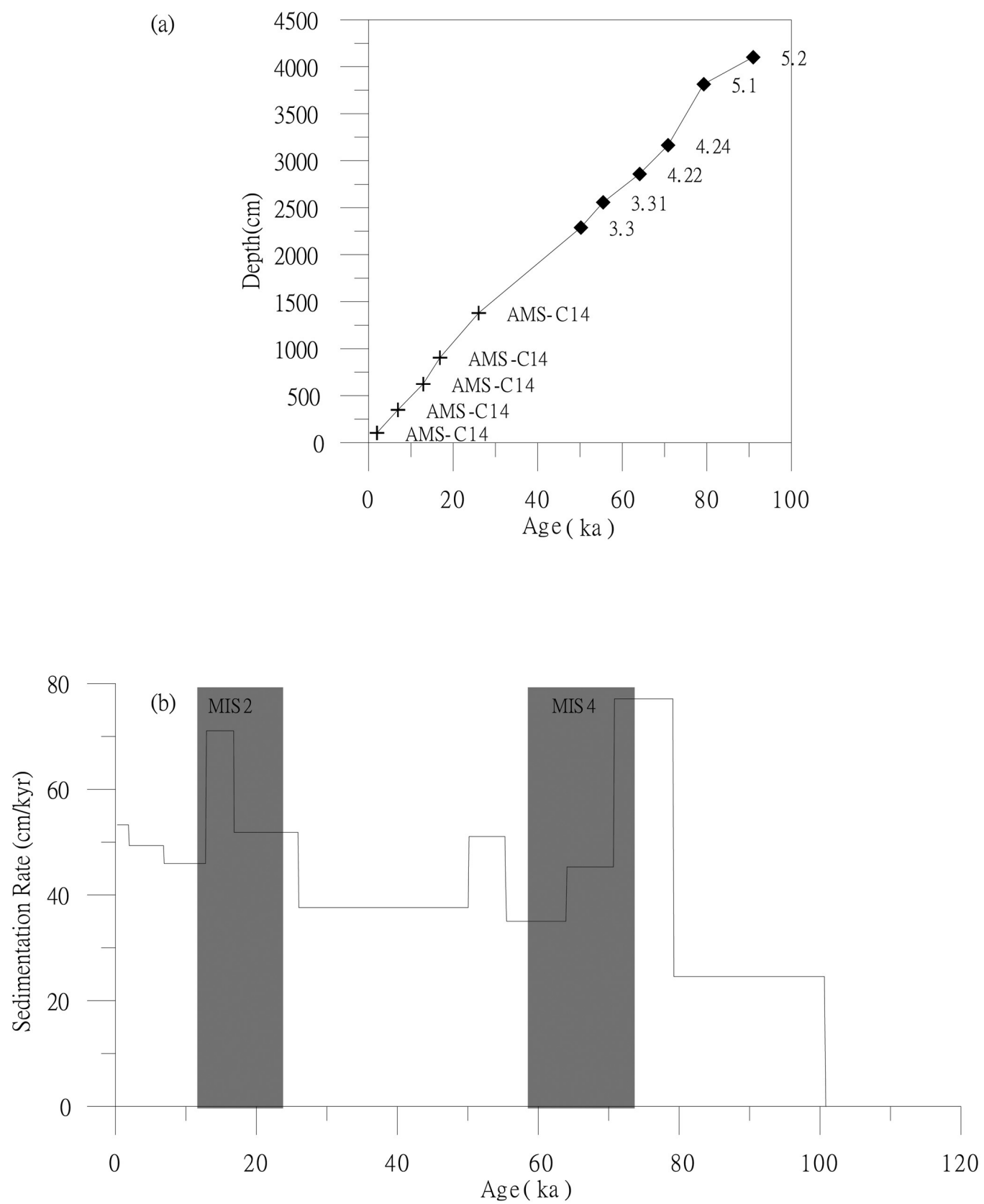

Fig. 3. (a) The age-depth scatter plot of core MD012404; (b) Linear sedimentation rates calculated on the basis of the age model of core MD012404. 
(Fig. 3b). This also suggests a relatively stable deposition environment at this site compared with core ODP 1202 (Wei et al. 2005). We conclude that the sedimentation rates at the MD012404 site are relatively higher in major glacial stages than in interglacial stages. Glacial sea level fall could be the main factor responsible for the high glacial sedimentation rates in the central Okinawa Trough, as the outcropped East China Sea continental shelves could be a source area for transporting more terrestrial sediments from the Yangtze River down-slope into the central Okinawa Trough.

\subsection{Comparison of MD012404 and ODP 1202 Oxygen Isotope Records}

The records of cores MD012404 and ODP 1202 were compared with a common chronostratigraphic framework. An age model of core ODP 1202 (Wei et al. 2005) was established based on planktic foraminifer $\left(N\right.$. dutertrei) oxygen isotope stratigraphy and AMS ${ }^{14} \mathrm{C}$ dating on foraminifer shells from selected intervals of a composite record of the core. The composite record of ODP 1202 was constructed using lithological and magnetic susceptibility data of cores from Site 1202 Hole B and D. Shipboard observations suggested the existence of a turbidite layer between 230 - 280 mbsf at Site 1202D (Shipboard Scientific Party 2002), we therefore attempted to only compare core data of Site 1202B from the top to $140 \mathrm{mbsf}$ with those of MD012404. There are also indications of some sandy layers occurring below $110 \mathrm{mbsf}$ at Site 1202B. Data measured from the samples located below the depth are presented in this study but should be interpreted with caution (Fig. 4).

Changes in global ice volume since the LGM was estimated to cause $0.9 \sim 1.0 \%$ oxygen isotope composition in the sea water (Fairbanks 1989, Schrag et al. 1996). Decreases in foraminifer oxygen isotope values from $\sim 20 \mathrm{ka}$ to the present in cores MD012404 and ODP 1202 reflect mainly the global ice volume change. The magnitudes of the oxygen isotope changes from the LGM to the present observed from these two cores are $\sim 1.6 \%$ (Fig. 4). After subtracting the effect associated with global ice volume changes, our data suggest a residual signal of $\sim 0.6-0.7 \%$, which probably reflects local effects of temperature and/or salinity changes in surface (ODP 1202) or deep (MD012404) water. The same magnitude of benthic foraminifer (Uvigerina spp.) oxygen isotope change since the LGM was also reported from the southern Okinawa Trough (Jian et al. 1996). The consistency of these two records implies relatively uniform deepwater conditions in the Okinawa Trough.

Compared with the MD012404 benthic isotope record, ODP 1202 planktic isotopes show more variability $(\sim 0.5-0.6 \%)$ in most glacial stages. This suggests an instability mode of SST and/or salinity in the surface water in the Okinawa Trough. The oxygen isotopes of surface water in the Okinawa Trough might be very sensitive to freshwater flux into this region because of the seaward migration of large river mouths during the lowered sea level. In contrast, the benthic isotope record from core MD012404 shows less variability $(\sim 0.1-0.2 \%)$, indicating more stable deepwater conditions in the glacial stages. Moreover, there is no noticeable oxygen isotope event analogous to the Younger Dryas in MD012404 benthic data during the transition from the LGM to the Holocene. This evidence suggests that the Younger Dryas event was more restricted to affecting surface water conditions in the western Pacific. Published records from the southern Okinawa Trough show an event in planktic oxygen iso- 
tope variations similar to the Younger Dryas (Li et al. 1997, Jian et al. 2000b). However, this event is not identifiable in the planktic isotopes of core ODP 1202 due to relative low-resolution sampling.

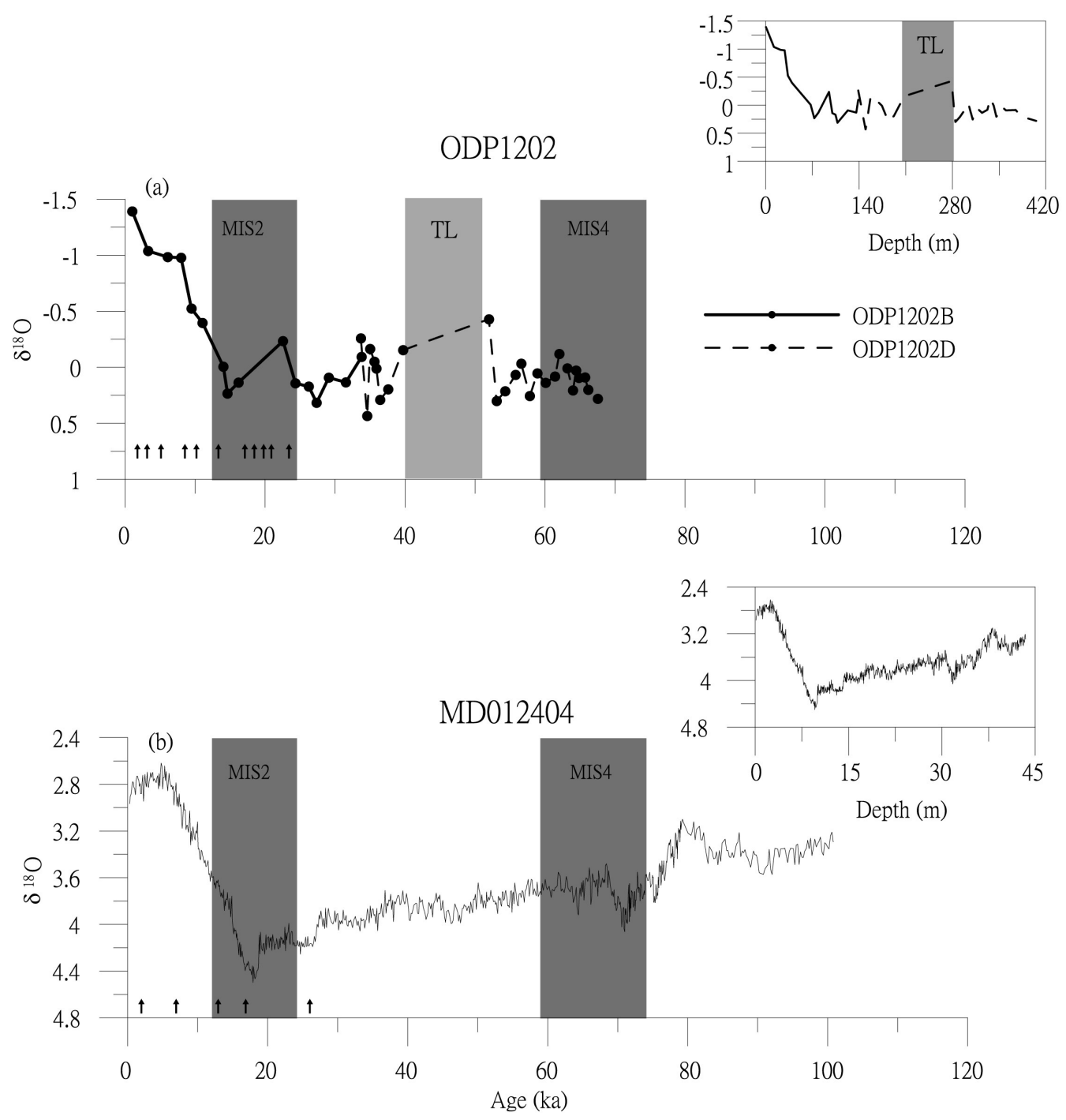

Fig. 4. (a) Planktic foraminifer $\delta{ }^{18} \mathrm{O}$ record of core ODP 1202 plotted versus age. Radiocarbon dates are indicated by black arrows (Wei et al. 2005). A turbidite layer (TL) observed between $230 \mathrm{mbsf}$ and $280 \mathrm{mbsf}$ of core $1202 \mathrm{D}$ is marked with a shaded area. (b) Planktic foraminifer $\delta^{18} \mathrm{O}$ record of core MD012404 plotted versus age. 


\subsection{Total Organic Carbon Records}

Sediment TOC content has long served as a useful proxy for paleoproductivity in paleoceanography. TOC content also can be used to indicate the flux of terrestrial sediment input in the Okinawa Trough (Sheu et al. 1995, Kao et al. 2003) as in the East China Sea, where tremendous amounts of terrestrial organic carbon particles are transported via large rivers to the sea floor where they are buried in the sediments. On the other hand, rapid sediment accumulation associated with the terrestrial sediment input also favors the preservation of organic carbon. Therefore, variations in TOC also may reflect sedimentation rate changes. A noticeable TOC spike observed from $~ 45 \mathrm{ka}$ interval in core ODP 1202 overlaps with a turbidite layer (Shipboard Scientific Party 2002), therefore this TOC maximum is not considered to be interpretable in terms of paleoproductivity or surface circulation changes. The TOC content curve of 1202B exhibits an increasing trend from the LGM to the Holocene (Fig. 5a). This trend could be attributed to either increasing productivity or increasing terrestrial input by large river runoff caused by a change of precipitation/evaporation on land due to the warmer climate in the Holocene. The southern Okinawa Trough is considered to be an important depocenter for particulate organic matter from the East China Sea shelf (Kao et al. 2003). Most organic matter deposited in this region comes from the Yangtze River and was transported southward by the Chinese Coastal Current across the Taiwan Strait and then deposited in the Southern Okinawa Trough (Kao et al. 2003). However, a least a part of the organic matter deposited in the southern Okinawa Trough was identified as being supplied from the runoff of the Lanyang River in northeastern Taiwan (Kao and Liu 1996).

In the central Okinawa Trough, the TOC content changes in core MD012404 display a pattern that is different from that observed with ODP 1202 (Fig. 5b). In the LGM-Holocene interval, TOC reached a maximum value in the early Holocene, showed a decreasing trend to the middle of the Holocene and then maintained a relative low value in the past few thousand years. In terms of long-term change, relatively high TOC contents can be identified at 5 broad intervals of $\sim 94-91 \mathrm{ka}, 82-76 \mathrm{ka}, 67-60 \mathrm{ka}, 46-37 \mathrm{ka}$ and $16-8 \mathrm{ka}$. The periodicity of the TOC changes approximates $23 \mathrm{kyr}$, which is very close to the precession cycles of orbital forcing. Besides the strong periodicity mirroring the orbital variations, the TOC data also express high frequency oscillations over millennial-to-centennial time scales.

Although the TOC record contains no distinct glacial-interglacial pattern, increasing trends starting from the early glacial periods (MIS 2 and MIS 4) are clearly observed (Fig. 5b). Minimum values of TOC are often associated with deglacial periods (MIS 4 to 3; MIS 2 to 1). The increased trends of TOC content observed in glacial stages imply either increased surface ocean productivity associated with stronger East Asian winter monsoons (Chen and Huang 1998, Chen et al. 1999) or the gradual emergence of East China Sea continental shelves to provide more terrestrial sediments and organic matter down-slope into the Okinawa Trough when the global sea level fell, or a combination of the two factors. In contrast, decreased intensity of winter monsoon wind in the warm deglacial stages might bring less organic matter produced in the surface water, and a gradual rising of sea level might shift river mouths landward and transport less organic matter into the Okinawa Trough. Relatively low C/N ( 9) data from sedimentary core record RN93-PC4 in the central Okinawa Trough (Ujiié et al. 2001) of 


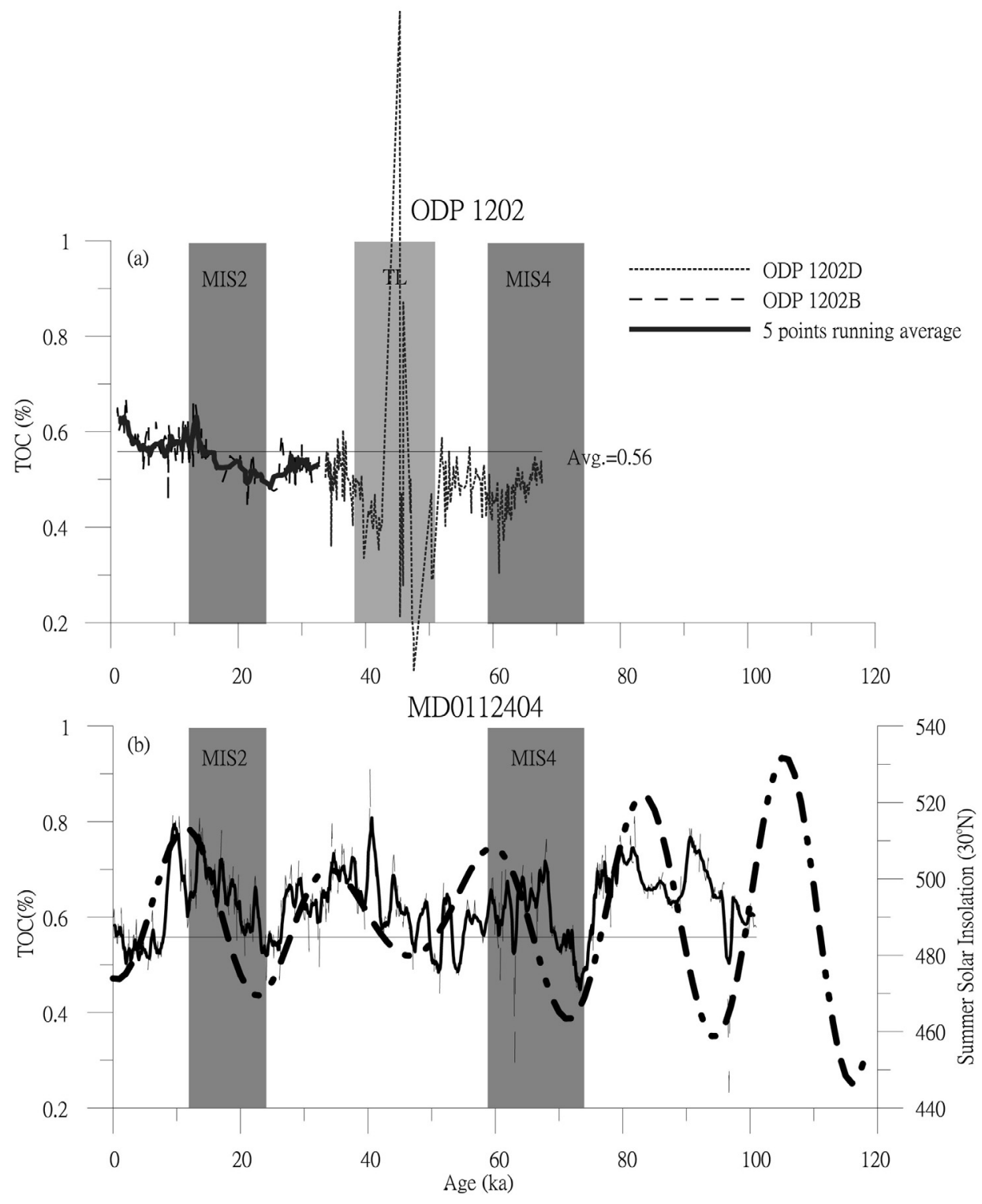

Fig. 5. Total organic carbon (TOC) content variations plotted versus age: (a) ODP1202 with a horizontal line indicating the average value of TOC and a pink curve that is calculated from a 5-point moving average of the TOC values (interpolated by a $\Delta \mathrm{t}=1 \mathrm{kyr}$ ); (b) MD012404 with a pink curve that is calculated from a 5-point moving average of the TOC values (interpolated by a $\Delta \mathrm{t}=1 \mathrm{kyr}$ ), and superimposed on these curves is the summer insolation $\left(30^{\circ} \mathrm{N}\right)$ that is primarily driven by precession forcing. 
the last $15 \mathrm{ka}$. has been suggested as a primary marine origin for organic matter in the sediments. While measurements of C/N on core MD012404 are not available in this study, evidence from the previous study suggests that variations in TOC content in core MD012404 reflect mostly monsoon or ocean circulation changes.

Solar insolation changes play an important role in controlling marine productivity in the East China Sea (Gong et al. 2003). Strong summer insolation could provide more energy to the photosynthetic phytoplankton and increase the productivity. Stalagmite paleoclimate records from eastern China indicate that strong summer insolation could enhance the East Asian summer monsoon intensity that brings more precipitation on land (Wang et al. 2001, Yuan et al. 2004). More precipitation on eastern China increases the river runoff and, in turn, transports more terrestrial organic matter into the East China Sea. The coincidence between the TOC content maximums in core MD012404 and the summer (June) solar insolation maximums in the North Hemisphere $\left(30^{\circ} \mathrm{N}\right)$ (Berger and Loutre 1991) indicate a possible linkage between surface ocean productivity response to local insolation changes (Fig. 5b). Moreover, an oceanic mechanism that links surface productivity in the East China Sea by varying fresh water flux from Yangtze River runoff has been proposed (Chen et al. 1995, Chen and Wang 1998, Chen and Wang 1999). The increased freshwater flux from the Yangtze River would induce upwelling of nutrient-enriched Kuroshio Intermediate Water generated from the South China Sea (Chen and Wang 1998). We infer that high summer solar insolation increases sensible and latent heating over the Asian continent as well as land-sea thermal contrast in the summer. Driven by this large thermal gradient in the summer, stronger East Asian summer monsoons are well developed. More precipitation brought by the summer monsoons would contribute to the river runoff of the Yangtze River and, in turn, induce more upwelling and high surface ocean productivity in the East China Sea.

Two extremely low TOC intervals appear at $97 \mathrm{ka}$ and $63 \mathrm{ka}$ in the MD012404 record. These low TOC intervals are also associated with very low carbonate contents, suggesting a strong dilution effect from the increases of other sediment components such as terrestrial silt or clay, and volcanic ash or pumice. Future studies are needed to identify the sediment components that dominate in these intervals and lower the TOC and carbonate contents.

\subsection{Carbonate Records}

Three major factors control the carbonate content in marine sediments, i.e., carbonate productivity, terrestrial sediment dilution and preservation/dissolution. The water depths of core sites ODP 1202 and MD012404 are $1274 \mathrm{~m}$ and $1397 \mathrm{~m}$, respectively, and both are well above the regional Western Pacific lysocline ( 3000 m) (Thunell et al. 1992). Therefore we conclude that the carbonate preservation/dissolution effects should not be responsible for controlling the main variations of carbonate content in these two cores. Variations in surface ocean productivity of calcareous microorganisms and terrestrial sediment dilution from riverine input therefore must be the two most important factors controlling the carbonate variations in the Okinawa Trough cores.

In comparing the two carbonate records (Fig. 6), we note that the average carbonate content in MD012404 is significantly higher than that in ODP 1202. This indicates either more 

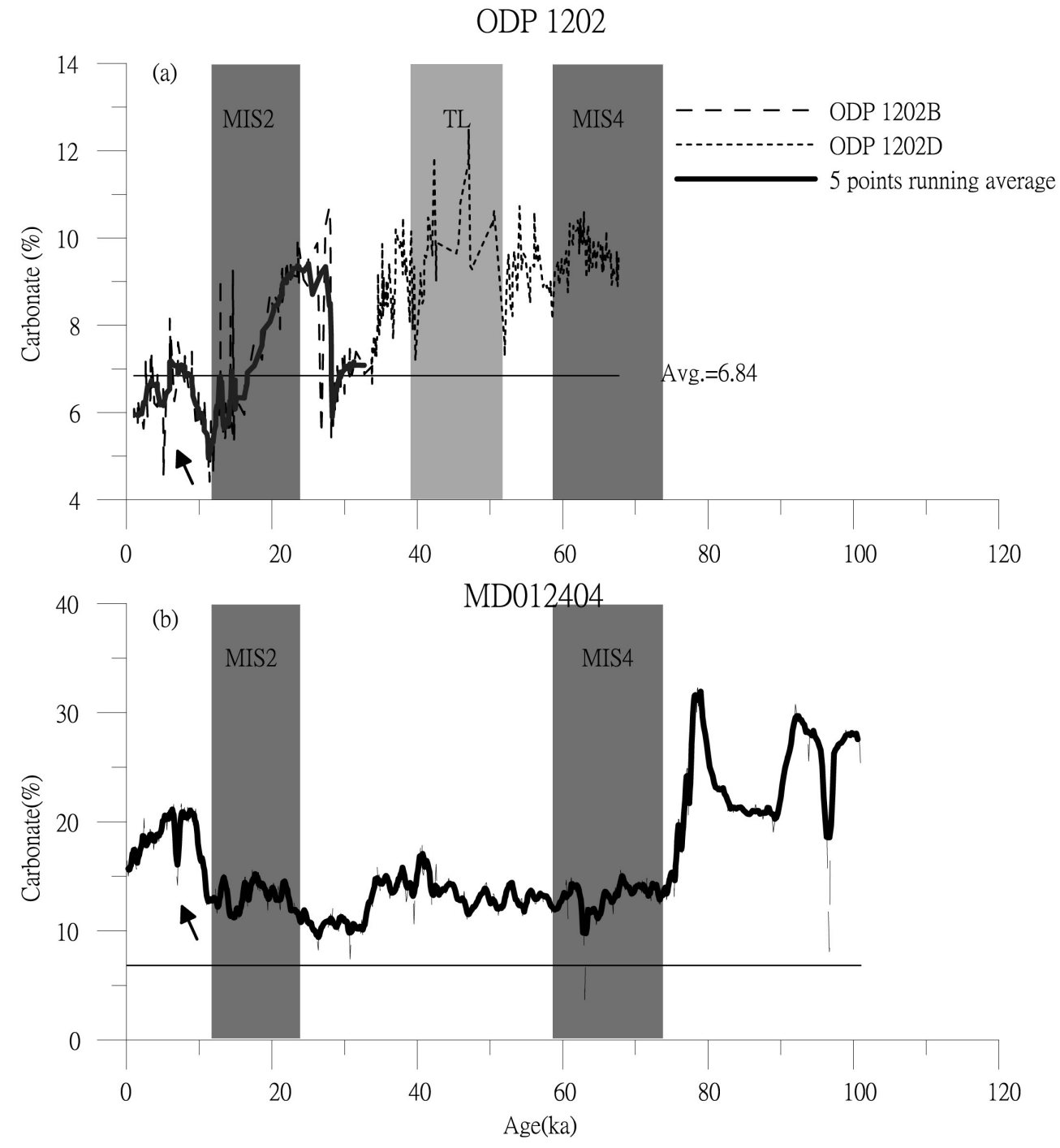

Fig. 6. Carbonate content variations plotted versus age (a) ODP1202 with a horizontal line indicating the average value of carbonate content and a pink curve that is calculated from a 5-point moving average of the carbonate content values (interpolated by $\Delta \mathrm{t}=1 \mathrm{kyr}$ ). The black arrow indicates an abrupt change in the Holocene interval of the core and a synchronous change also shown in core MD012404. (b) MD012404 with a pink curve that is calculated from a 5-point moving average of the carbonate content values (interpolated by a $\Delta \mathrm{t}=1 \mathrm{kyr}$ ). 
terrestrial dilution or less carbonate productivity in the southern Okinawa Trough. In core MD012404, noticeable changes in carbonate content in major glacial/interglacial stages are observed. For example, high carbonate content reaches up to $30 \%$ in late MIS 5 while the carbonate content stays low in most MIS 4 to MIS 2. Global sea level fluctuations associated with the glacial/interglacial cycles changed the exposure of East China Sea continental shelves and/or the proximity of large river mouths to the MD012404 site. The close relationship between the carbonate content and sea level fluctuations suggests terrestrial sediment dilution dominates the MD012404 carbonate record. In ODP 1202, carbonate variations reveal a longterm decreasing trend since the late MIS 3 (Fig. 6a). The decreasing trend could be attributed to an increase of terrestrial input into the southern Okinawa Trough. This interpretation is consistent with that for the long-term trend of increased TOC content in the same core (Fig. 5a). We also observed a short minimum of carbonate content in the middle Holocene at $\sim 5 \mathrm{ka}$, and this event seems to be synchronous with a short event carbonate minimum in core MD012404. Whether an abrupt change in calcareous productivity, terrestrial dilution or intermediate/ deepwater circulation is responsible for this event warrants further study.

\section{CONCLUSIONS}

In this study of foraminifer oxygen isotope, biogenic sediment components of TOC and carbonate of the Late Quaternary sediment cores MD012404 and ODP 1202 from the Okinawa Trough, we established high-resolution stratigraphies and also identified important processes related to East Asian monsoon or global sea level changes that controlled the sediment compositions of the cores. A high-resolution benthic foraminifer $\delta^{18} \mathrm{O}$ record generated from the core MD012404 was used as a chronological framework of the past 100000 years. The estimated average sedimentation rate based on this age model is $\sim 50 \mathrm{~cm} \mathrm{ky}^{-1}$. The continuous record of core MD012404 shows that cores taken from such high sedimentation rate sites can be used to investigate details in orbital-scale to even millennial-scale climate variability expressed in the Western Pacific. The extremely high sedimentation rate observed from core ODP 1202 suggests that the southern Okinawa Trough is a sediment depocenter with large terrestrial sediment input. The comparison of MD012404 and ODP 1202 biogenic records suggests that the terrestrial dilution effect is a major factor responsible for controlling the variations of carbonate contents in the Okinawa Trough. Surface ocean productivity changes in the central Okinawa Trough show more dominant $23 \mathrm{kyr}$ cycles and indicate sensitivity to East Asian monsoons and precipitation/river runoff. Changes in local summer solar insolation or precipitation-induced intermediate/deepwater upwelling might also play important roles in controlling the productivity changes. Superimposed on the $23 \mathrm{kyr}$ cycles, the MD012404 TOC also exhibits high-frequency, millennial-scale oscillations that need future studies to compare them with northern high-latitude climate records that contain similar features.

Acknowledgements We thank the scientists who contributed their valuable time on board in order to obtain such high-quality cores in the IMAGES 2001 WEPAMA cruise. We thank all the members in the Core Repository and Laboratory, National Center for Ocean Research (NCOR) for helping with me the measurements. This research was supported by the National 
Science Council (NSC92-2611-M-019-016), Academia Sinica [Asian Paleoenvironmental Changes (APEC) Projects], and the National Taiwan Ocean University, R.O.C..

\section{REFERENCES}

Bassinot, F. C., A. Baltzer, M. T. Chen, P. DeDeckker, W. Khuhnt, M. Levitan, D. Nurnberg, T. Oba, M. Prentice, M. Sarnthein, M. Situmorang, R. Tiedemann, A. Holbourn, T. Kiefer, U. Pflaumann, and S. Rothe, 2002: Scientific Report of the WEPAMA Cruise, MD122/IMAGES VII, 453.

Berger, A., and M. F. Loutre, 1991: Insolation values for the climate of the last 10 million years. Quat. Sci.Rev., 10, 297-317.

Chang, F. Y., S. J. Kao, and K. K. Liu, 1991: Analysis of Organic and Carbonate Carbon in Sediments. Acta Oceanographica Taiwanica, 140-150.

Chen, C. T. A., R. Ruo, S. C. Pai, C. T. Liu, and G. T. F. Wong, 1995: Exchange of water masses between the East China Sea and the Kuroshio off northwestern Taiwan. Cont. Shelf Res., 15, 19-39.

Chen, C. T. A., and S. L. Wang, 1998: Influence of intermediate water in the western Okinawa Trough by the outflow from the South China Sea.J. Geophys. Res., 103, 12683-12688.

Chen, C. T. A., and S. L. Wang, 1999: Carbon, alkalinity and nutrient budgets on the East China Sea continental shelf. J. Geophys. Res., 104, 20675-20686.

Chen, M. T., and C. Y. Huang, 1998: Ice-Volume Forcing of Winter Monsoon Climate in the South China Sea. Paleoceanography, 13, 622-633.

Chen, M. T., C. H. Wang, C. Y. Huang, L. Wang, and M. Sarnthein, 1999: A late Quaternary planktonic foraminifer faunal record of rapid climatic changes from the South China Sea. Marine Geol., 156, 85-108.

Fairbanks, R. G., 1989: A 17000-year glacio-eustatic sea level record: influence of glacial melting rates on the Younger Dryas event and deep-ocean circulation. Nature, 342, 637-616.

Gong, G. C., Y. H. Wen, B. W. Wang, and G. J. Liu, 2003: Seasonal variation of chlorophyll a concentration, primary production and environmental conditions in the subtropical East China Sea. Deep-Sea Res. II, 50, 1219-1236.

Hsueh, Y., 2000: The Kuroshio in the East China Sea. J. Marine Sys., 24, 131-139.

Huang, C. Y., Y. L. Chiu and M. Zhao, 2005: Sedimentological features of silt and sand depositions of ODP Site 1202, Leg 195, in southern Okinawa Trough. Terr. Atmos. Ocean. Sci., 16, 19-44.

Imbrie, J., J. D. Hays, D. G. Martinson, A. McIntyre, A. C. Mix, J. J. Morley, N. G. Pisias, W. L. Prell, and N. J. Shackleton, 1984: The Orbital Theory of Pleistocene Climate: Support from a Revised Chronology of the Marine $\delta{ }^{18}$ O Record. D. Reidel Publ. Comp., 269-305.

Jian, Z., B. Li, B. Huang, and J. Wang, 2000a: Globorotalia truncatulinoides as indicator of upper-ocean thermal structure during the Quaternary: evidence from the South China Sea and Okinawa Trough. Palaeogeog., Palaeoclimatolog., Palaeoecolog., 162, $287-298$. 
Jian, Z., B. Li, U. Pflaumann, and P. Wang, 1996: Late Holocene cooling event in the western Pacific. Sci. China, 39, 543-550.

Jian, Z., P. Wang, Y. Saito, J. Wang, U. Pflaumann, T. Oba, and X. Cheng, 2000b: Holocene Variability of the Kuroshio Current in the Okinawa Trough, Northwestern Pacific Ocean. Earth Planet. Sci. Lett., 184, 305-319.

Kao, S. J., F. J. Lin, and K. K. Liu, 2003, Organic carbon and nitrogen contents and their isotopic compositions in surficial sediments from the East China Sea shelf and the southern Okinawa Trough. Deep-Sea Res. II, 50, 1203-1217.

Kao, S. J., and K. K. Liu, 1996: Particulate organic carbon export from a subtropical mountainous river (Lanyang Hsi) in Taiwan. Limnol. Oceanogr., 41, 1749-1757.

Li, B., Z. Jian, and P. Wang, 1997: Pulleniantina obliquiloculata as a Paleoceanographic indicator in the souh Okinawa Trough during the Last 20000 Years. Marine Micropaleontol., 32, 59-69.

Li, T., Z. Liu, M. A. Hall, S. Berne, Y. Saito, S. Cang, and Z. Cheng, 2001: Heinrich Event Imprints in the Okinawa Trough: Evidence from Oxygen Isotope and Planktonic Foraminifera. Palaeogeog., Palaeoclimatolog., Palaeoecolog., 176, 133-146.

Liu, Z., Y. Saito, T. Li, S. Berne, Z. Cheng, P. Li, Z. Li, F. Guichard, and G. Floch, 1999: Millennial-scale paleoceanography in the Okinawa Trough during the Late Quaternary period. Chinese Sci. Bull., 44, 1705-1709.

Martinson, D. G., N. G. Pisias, J. D. Hays, J. Imbrie, T. C. Moore Jr., and N. J. Shackleton, 1987: Age Dating and the Orbital Theory of the Ice Ages: Development of a HighResolution 0 to 300,000-Year Chronostratigraphy. Quat. Res., 27, 1-29.

Pisias, N. G., D. G. Martinson, T. C. Moore Jr., N. J. Shackleton, W. L. Prell, J. D. Hays, and G. Boden, 1984: High Resolution Statigraphic Correlation of Benthic Oxygen Isotopic Records Spanning the Last 300,000 Years. Marine Geol., 56, 119-136.

Prell, W. L., J. Imbrie, D. G. Martinson, J. J. Morley, N. G. Pisias, N. J. Shackleton, and H. F. Streeter, 1986: Graphic Correlation of Oxygen Isotope Stratigraphy Application to the Late Quaternary. Paleoceanogr., 1, 137-162.

Schrag, D. P., G. Hampt, and D. W. Murray, 1996: Pore Fluid Constraints on the Temperature and Oxygen Isotopic Composition of the Glacial Ocean. Science, 272, 1930-1932.

Sheu, D. D., W. C. Jou, M. J. Chen, W. Y. Lee, and S. Lin, 1995: Variations of Calcium Carbonate, Organic Carbon and Their Isotopic Compositions in Surface Sediments of the East China Sea. TAO, 6, 115-128.

Shieh, Y. T., C. H. Wang, M. P. Chen, and Y. L. Yung, 1997: The Last Glacial Maximun to Holocen environment changes in the southern Okinawa Trough. J. Asian Earth Sci., 15, 3-8.

Su, C. C., and C. A. Huh, 2002: ${ }^{210} \mathrm{~Pb},{ }^{137} \mathrm{Cs}$ and ${ }^{239,240} \mathrm{Pu}$ in East China Sea sediments: sources, pathways and budgets of sediments and radionuclides. Marine Geol., 183, 163-178.

Shipboard Scientific Party, 2002: Site 1202. In Salisbury, M.H., Shinohara, M., Richter, C., et al., Proc. ODP, Init. Repts., 195, 1-46 [CD-ROM]. Available from: Ocean Drilling Program, Texas A\&M Univ., College Station TX 77845-9547, USA. 
Szeremeta, N., F. C. Bassinot, C. Kissel, Y. Bault, K. Guibert, K. Dubois, C. Laj, and M. Pagel, 2000: Stretching of sedimentary series collected through piston coring: evidences, implications and corrections. EOS, Transactions, $\mathbf{8 1 .}$

Tanaka, Y., 2003: Coccolith fluxes and species assemblages at the shelf edge and in the Okinawa Trough of the East China Sea. Deep-Sea Res. II, 50, 503-511.

Thouveny, N., E. Moreno, D. Delanghe, L. Candon, Y. Lancelot, and N. J. Shackleto, 2000: Rock-magnetic detection of distal ice refted debris: clue for the identification of Heinrich layers on the Portugiese margin. Earth Planet. Sci. Lett., 180, 61-75.

Thunell, R., Q. Miao, S. E. Calvert, and T. F. Pedersen, 1992: Glacial-Holocene biogenic sedimentation patterns in the South China Sea: productivity variations and surface water $\mathrm{pCO}_{2}$. Paleoceanogr., 7, 143-162.

Ujiié, H., Y. Hatakeyama, X. X. Gu, S. Yamamoto, R. Ishiwatari, and L. Maeda, 2001: Upward decrease of organic $\mathrm{C} / \mathrm{N}$ ratios in the Okinawa Trough cores: proxy for tracing the post-glacial retreat of the continental shore line. Palaeogeog., Palaeoclimatolog., Palaeoecolog., 165, 129-140.

Ujiié, H., and Y. Ujiié, 1999: Late Quaternary course changes of the Kuroshio Current in the Ryukyu Arc region, northwestern Pacific Ocean. Marine Micropaleontol., 37, $23-40$.

Ujiié, Y., H. Ujiié, A. Taira, T. Nakamura, and K. Oguri, 2003: Spatial and temporal variability of surface water in the Kuroshio source region, Pacific Ocean, over the past 21,000 years: evidence from planktonic foraminifera. Marine Micropaleontol., 49, 335-364.

Wang, Y. J., H. Cheng, R. L. Edwards, Z. S. An, J. Y. Wu, C. C. Shen, and J. A. Dorale, 2001: A High-Resolution Absolute-Dated Late Pleistocene Monsoon Record from Hulu Cave, China. Science, 294, 2345-2348.

Wei, K. Y., H. S. Mii, and C. Y. Huang, 2005: Age Model and Oxygen Isotope Stratigraphy of Site ODP1202 in the Southern Okinawa Trough, Northwestern Pacific.Terr. Atmos. Ocean. Sci., 16, 1-17.

$\mathrm{Xu}, \mathrm{X}$., and M. Oda, 1999: Surface-water evolution of the eastern East China Sea during the last 36,000 years. Marine Geol., 156, 285-304.

Yuan, D., H. Cheng, R. L. Edwards, C. A. Dykoski, M. J. Kelly, M. Zhang, J. Qing, Y. Lin, Y. Wang, J. Wu, J. A. Dorale, Z. An, and Y. Cai, 2004: Timing, Duration, and Transitions of the Last Interglacial Asian Monsoon. Science, 304, 575-578. 